\title{
Crop management goes high-tech
}

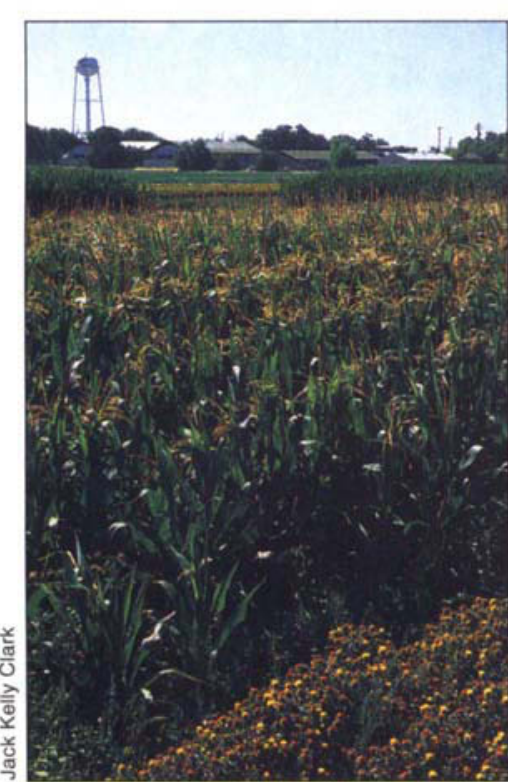

Aerial photos helped diagnose infiltration problems in UC Davis corn trials.
W ith substantial fixed costs for every field they plant, growers know that patches of low yield can be costly. Furthermore, the reasons for patchiness may be difficult to diagnose ranging from diseases and pests, to irrigation and fertilization problems.

Now high-tech techniques can help growers pinpoint and resolve such problems more quickly. UC Davis agronomist Ford Denison has used computer image processing to derive sitespecific information from aerial photographs of UC Davis experimental fields (see facing page).

"Aerial images can be processed to provide detailed information on spatial differences in soil properties and crop performance," Denison says. Aerial photos can be taken early in the growing season when there may still be time to correct any problems. They are relatively inexpensive. For example, each aerial photograph covering a one-square mile area might cost $\$ 35$; the overhead cost of a single flight is typically $\$ 145$.

Before recent innovations in computer hardware and software, it was difficult to obtain meaningful numerical data from aerial photos. However, new high-tech tools are now widely available - such as a personal computer equipped with slide scanner and image processing software.

Growers can use such tools to analyze infrared aerial photos and diagnose field problems at specific sites.

Denison is director of the Long Term Research on Agricultural Systems (LTRAS) project at UC Davis, now in the second cropping year of a 100-year experiment which will investigate the relationship between sustainability and external inputs.

To study nitrogen fixation, Denison had been computer-processing images taken with a video camera of root nodules under a microscope.

"It occurred to me: Why not do this with aerial images of crops? The software doesn't care where image comes from."

Aerial imagery doesn't substitute for field monitoring, but it provides a different kind of information and makes trips to the field more effective. Such photos were used to diagnose the reason for poor corn yields in the conventional trials of UC's Sustainable Agricultural Farming Systems (SAFS) project at Davis.
Robert Miller, UC Davis soils specialist, noted low yields in 1992 and 1993. The following year, Denison produced a computer-processed aerial photo of the plot. A uniformly healthy plot would have been bright red. Mottled colors in the SAFS photo showed where the corn was under stress. "We had an infiltration problem causing a water deficit in the conventional plot," Miller says. "You could see it clear as day."

Aerial photography is just one method of gathering data for site-specific management in another UC study funded by the California Department of Food and Agriculture's Fertilizer Research and Education Program (FREP).

"With the high cost of land in California, growers practice intensive management. They need more data to make good decisions about pest control, irrigation, and fertilization," says Stuart Pettygrove, UC Davis soils specialist.

Researchers are combining aerial photography with soil and plant tissue sampling and yield monitoring. A combine-mounted machine measures the yield rate of grain as it is being harvested. Coupled with a satellite-based global positioning system, this machine generates a detailed map of yield patterns across a field.

In Yolo County, a cooperating grower knew there were parts of a field where herbicides had failed and the canarygrass and bromegrass were taller than the wheat. From the processed aerial photos, the researchers hope to index the weed intensity and match it with yield. "We want to be able to tell him how much the weeds cost him in yield," Pettygrove says.

"Personal computers place powerful tools in the hands of growers," Miller says. "You don't even have to own a scanner." He says it costs about $\$ 3$ to get a photo scanned and that software is readily available to do the analysis.

Richard Plant, professor in the departments of agronomy and range science and biological and agricultural engineering, explains that the cost of software varies with what they can do.

Adobe Photoshop costs $\$ 500-600$ and allows you to view the image. Others allow users to view and analyze the image: IDRISI for Windows made by Clark University in Worcester, Mass., for about $\$ 400$; and Arcview by Environmental System Research Institute in Redlands for about $\$ 900$.

- Editor 